\title{
Pengaruh Budaya Organisasi Terhadap Kinerja Karyawan (Studi di Divisi Account Executive PT Agrodana Futures)
}

\author{
Alfitri Rijanto $^{1 *}$ dan Mukaram ${ }^{2}$ \\ ${ }^{1}$ Jurusan Administrasi Niaga, Politeknik Negeri Bandung, Indonesia \\ ${ }^{2}$ Jurusan Administrasi Niaga, Politeknik Negeri Bandung, Indonesia
}

\begin{abstract}
:
This research is to know the influence of organizational culture on employee performance division of account executive PT Agrodana Futures. PT Agrodana Futures is a futures trading company specializing in foreign exchange trading of Asian stock indices. The influencing variables are organizational culture with dimensions that refer to Cameron and Quinn (2006) ie clan, adhocracy, market, and hierarchy. While the variables that are influenced is the performance of employees with dimensions that refer to the Dharma (2003) namely the quality of work, quantity of work, and timeliness. The method of this research is descriptive quantitative by using nonprobability sampling technique that is saturated sampling. The results showed that organizational culture has a mean value of 4.444 and employee performance with a mean value of 4.3670 which means both are in very good category. Meanwhile, organizational culture of account executive division at PT Agrodana Futures gives $26.3 \%$ influence on employee performance.
\end{abstract}

Keywords: organizational culture, employee performance, OCAI

\section{PENDAHULUAN}

PT Agrodana Futures adalah perusahaan perdagangan berjangka dengan spesialisasi dalam perdagangan valuta asing indeks saham Asia. PT Agrodana Futures menawarkan jasa finansial yang profesional, inovatif, dan fleksibel untuk memenuhi kebutuhan investasi setiap klien, dengan menggunakan beragam produk investasi. PT Agrodana Futures memiliki ketentuan jam kerja yaitu masuk pukul 08.30 dan pulang ada pukul 17.30 dengan jam istirahat mulai dari pukul 12.00 sampai 13.00. Akan tetapi sering ditemukan adanya karyawan yang memakai jam kerja untuk istirahat lebih awal dan terlambat kembali bekerja setelah waktu istirahat. Hal ini merupakan faktor yang akan menganggu pencapaian target perusahaan.

*Email korespondensi:

Alfitri Rijanto

alfitririjanto@gmail.com
Faktor keterlambatan tersebut dapat berpengaruh terhadap produktivitas perusahaan, berikut dapat dilihat pada Gambar 1. mengenai data rata-rata jumlah keterlambatan karyawan yang terlambat di divisi account executive PT Agrodana Futures setiap bulannya. Adanya peningkatan keterlambatan karyawan selama tahun 2017 membuktikan bahwa karyawan kurang

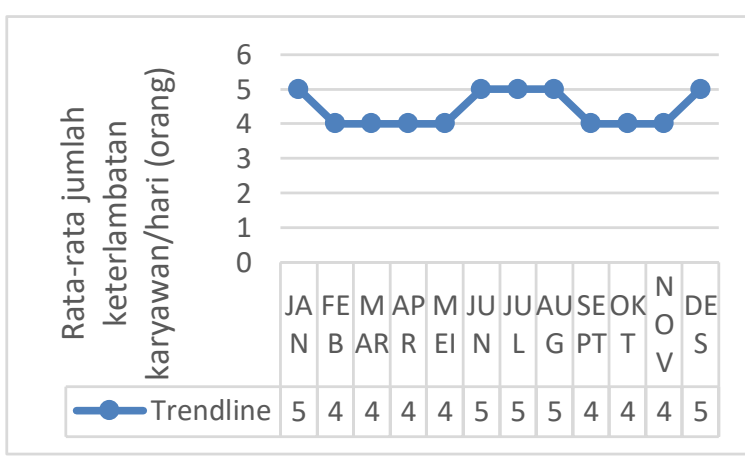

Sumber: PT Agrodana Futures (2018)

Gambar 1. Trendline Jumlah Keterlambatan Karyawan Tahun 2017 
disiplin dalam mentaati peraturan perusahaan.

Keterlambatan karyawan dapat menghambat produktivitas perusahaan, karena jam kerja yang dipakai untuk bekerja tidak efektif. Selain masalah keterlambatan karyawan, pencapaian margin yang diperoleh melalui nasabah yang berinvestasi juga memberikan pengaruh terhadap produktivitas dan kinerja suatu organisasi.

Selain masalah keterlambatan karyawan, pencapaian margin yang diperoleh melalui nasabah yang berinvestasi juga memberikan pengaruh terhadap produktivitas dan kinerja suatu organisasi, hal ini bisa dilihat pada Tabel 1 .

\section{Tabel 1. Kinerja Karyawan Divisi Account Executive Tahun 2017}

\begin{tabular}{|c|l|c|c|}
\hline No. & \multicolumn{1}{|c|}{ Bulan } & Target & Hasil \\
\hline 1. & Januari & $90 \%$ & $35 \%$ \\
\hline 2. & Februari & $90 \%$ & $40 \%$ \\
\hline 3. & Maret & $90 \%$ & $35 \%$ \\
\hline 4. & April & $90 \%$ & $45 \%$ \\
\hline 5. & Mei & $90 \%$ & $60 \%$ \\
\hline 6. & Juni & $90 \%$ & $70 \%$ \\
\hline 7. & Juli & $90 \%$ & $55 \%$ \\
\hline 8. & Agustus & $90 \%$ & $65 \%$ \\
\hline 9. & September & $90 \%$ & $70 \%$ \\
\hline 10. & Oktober & $90 \%$ & $65 \%$ \\
\hline 11. & November & $90 \%$ & $65 \%$ \\
\hline 12. & Desember & $90 \%$ & $75 \%$ \\
\hline
\end{tabular}

Sumber: PT Agrodana Futures (2018)

Berdasarkan Tabel 1. dapat dilihat bahwa pencapaian target selama tahun 2017 cenderung fluktuatif. Berdasarkan wawancara informal dengan Wakil Pialang PT Agrodana Futures, alasan target perusahaan tidak bisa dicapai oleh karyawan adalah adanya kendala dalam mendapatkan nasabah.

Selain itu, PT Agrodana Futures Bandung memiliki motto "SERVICE EXCELLENCE" yang mengacu untuk memberi pelayanan terbaik, merencanakan dan beradaptasi dengan perkembangan zaman serta menempatkan diri untuk pertumbuhan jangka panjang, sehingga harga di Bursa Berjangka Jakarta dapat menjadi acuan atau referensi Nasional dan bahkan Internasional serta menerapkan keterbukaan, jujur, terpercaya, dan bertanggungjawab. Akan tetapi kendala yang sering ditemui adalah masalah kepercayaan, dikarenakan banyak calon nasabah yang belum terlalu mempercayai untuk melakukan investasi di perdagangan berjangka. Hal ini masih merupakan bagian kecil dalam mengetahui budaya organisasi yang ada di PT Agrodana Futures. Berdasarkan uraian atas, untuk mengetahui budaya organisasi lebih lanjut di PT Agrodana Futures maka dilakukan penelitian dengan mengambil judul "Pengaruh Budaya Organisasi Terhadap Kinerja Karyawan Divisi Account Executive di PT Agrodana Futures".

\section{Rumusan Masalah}

Berdasarkan latar belakang masalah yang telah diuraikan, maka rumusan masalah dari penelitian ini adalah:

1. Bagaimana budaya organisasi karyawan divisi account executive PT Agrodana Futures Bandung?

2. Bagaimana kinerja karyawan karyawan divisi account executive PT Agrodana Futures Bandung?

3. Apakah ada pengaruh positif yang signifikan antara budaya organisasi terhadap kinerja karyawan karyawan divisi account executive PT Agrodana Futures Bandung?

\section{Maksud dan Tujuan}

Tujuan dari penelitian yang akan dilakukan untuk menyusun skripsi ini adalah sebagai berikut:

1. Untuk mengetahui budaya organisasi karyawan divisi account executive PT Agrodana Futures Bandung.

2. Untuk mengetahui kinerja karyawan divisi account executive PT Agrodana Futures Bandung.

Untuk mengetahui pengaruh budaya organisasi terhadap kinerja karyawan divisi 
account executive PT Agrodana Futures Bandung.

\section{KAJIAN LITERATUR Budaya Organisasi}

Budaya organisasi dapat dijadikan identitas pembeda dari satu organisasi dengan organisasi lainnya sesuai dengan ciri khas yang dimilikinya. Budaya organisasi adalah nilai dasar organisasi berupa keyakinan, norma-norma dan cara belajar orang-orang di dalam organisasi yang merupakan perekat dan ciri khas organisasi yang bisa membedakan dengan organisasi lainnya (Triatna, 2015). Sedangkan definisi budaya organisasi menurut Kreitner \& Kinicki (2014) adalah membagi nilai-nilai dan kepercayaan-kepercayaan yang mendasari identitas perusahaan.

\section{Competing Values Framework (CVF)}

Pada tahun 2000, Cameron dan Quinn memperkenalkan suatu kerangka budaya organisasi yang disebut dengan Competing Values Framework (CVF). CVF ini memiliki dua dimensi yang pertama adalah dimensi membedakan keefektifan kriteria yang menekankan fleksibilitas, kebijaksanaan, dan dinamisme dari kriteria yang menekankan stabilitas, ketertiban, dan kontrol. Dimensi yang kedua adalah dimensi yang membedakan kriteria efektivitas menekankan orientasi internal, integrasi, dan kesatuan dari kriteria yang menekankan orientasi eksternal, diferensiasi, dan persaingan. Kemudian dari dua dimensi tersebut membentuk empat kuadran, masing-masing mewakili seperangkat indikator efektivitas organisasi yang berbeda. Gambar 2. menggambarkan hubungan kedua dimensi ini satu sama lain. Indikator efektivitas ini mewakili apa yang orang-orang nilai tentang kinerja organisasi.

Pada gambar 2. dapat dilihat bahwa kuadran pertama adalah dimensi clan, dimensi ini menjelaskan bahwa setiap anggota dalam organisasi memiliki rasa kebersamaan dan kekeluargaan. Para pemimpin atau pemimpin organisasi

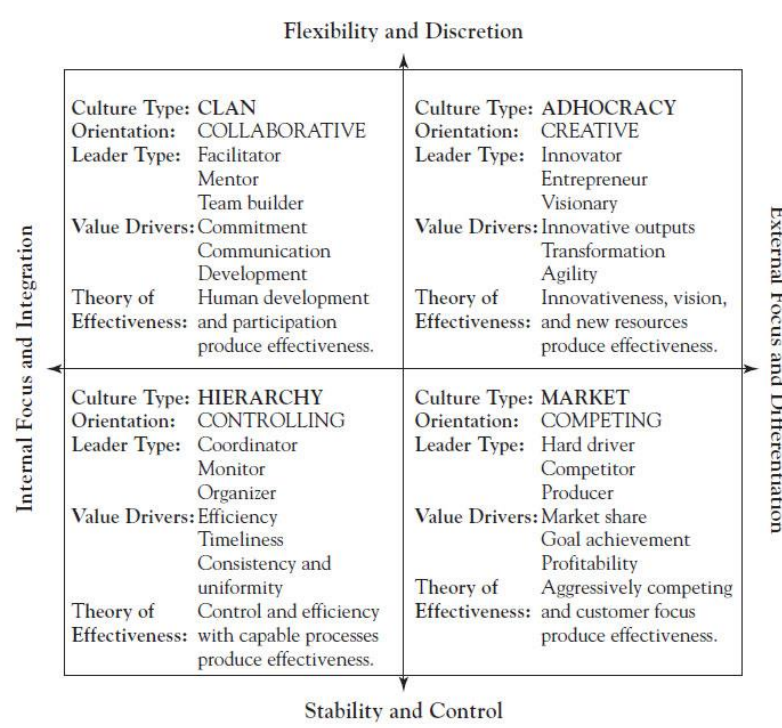

Sumber: Cameron dan Quinn (2006:46)

Gambar 2. The Competing Values Framework (CVF)

dianggap sebagai mentor dalam organisasi. Budaya ini memiliki ciri yaitu kerjasama tim, program keterlibatan karyawan, komitmen karyawan yang tinggi terhadap organisasi dan rekan kerja, komitmen organisasi yang tinggi kepada karyawan serta pengembangan karyawan yang dilakukan di organisasi (Cameron dan Quinn, 2006:53).

Selanjutnya adalah dimensi kedua yaitu adhocracy, yang memiliki pengertian bahwa budaya ini menuntut inovasi dan inisiatif serta menciptakan produk baru dan jasa untuk mengantisipasi dan mempersiapkan kebutuhan dimasa depan. Tugas utama manajemen adalah mendukung dan mendorong terciptanya semangat entrepreneurship dan kreativitas (Cameron dan Quinn, 2006:43).

Dimensi yang ketiga adalah market, yang berorientasi pada hasil di tempat kerja. Tujuan utama dari budaya ini adalah melakukan transaksi dengan para pemangku kepentingan lainnya untuk menciptakan keunggulan kompetitif. Daya saing dan produktivitas pada dasarnya membentuk dasar sebuah organisasi yang didorong oleh budaya pasar itu sendiri. Budaya ini memiliki ciri khas yaitu menang adalah segalanya dan daya saing organisasi mengalir ke setiap 
individu karena orientasi budaya ini adalah kompetisi yang bersaing secara sehat dalam lingkungan organisasi maupun diluar (Cameron dan Quinn, 2006:40).

Dimensi yang terakhir adalah hierarchy, yaitu budaya perusahaan yang ditandai dengan adanya bentuk perusahaan yang resmi dan terstruktur. Prosedur standar berfungsi untuk mengatur tindakan karyawan. Budaya ini berorientasi pada pengawasan kontrol sehingga dapat menghasilkan efisiensi dalam melakukan pekerjaan, sedikit waktu yang dibutuhkan, konsisten serta berusaha untuk mencapai target bersama. Perhatian jangka panjang untuk organisasi adalah stabilitas prediktabilitas, dan efisensi (Cameron dan Quinn, 2006: 38).

\section{Kinerja Karyawan}

Kinerja karyawan berfungsi untuk mengukur sejauh mana karyawan mampu menyelesaikan pekerjaannya secara efektif dan efisien. Kinerja karyawan menurut Mangkunegara (2010) bahwa kinerja karyawan (prestasi kerja) adalah hasil kerja secara kualitas dan kuantitas yang dicapai oleh seseorang karyawan dalam melaksanakan tugasnya sesuai dengan tanggung jawab yang diberikan kepadanya. Sedangkan kinerja karyawan menurut Stephen \& Stephen (2016) adalah "Employee performance is a term typical to the human resource field where employee performance can refer to the ability of employees to achieve organizational goals more effectively and efficiently". Pengertian tersebut dapat diartikan bahwa kinerja karyawan adalah istilah yang khas untuk bidang sumber daya manusia dimana kinerja karyawan dapat merujuk kemampuan karyawan untuk mencapai tujuan organisasi lebih efektif dan efisien. Begitu juga menurut Sulistiyani \& Rosidah (2003) mengemukakan bahwa kinerja merupakan hasil kerja yang dilakukan karyawan selama periode waktu tertentu.

Pengertian menurut beberapa ahli diatas dapat disimpulkan bahwa kinerja karyawan adalah standar kinerja untuk mengukur hasil kerja yang dilakukan oleh karyawan baik secara kualitas dan kuantitas yang menjadi tanggungjawab masing-masing karyawan untuk mencapai tujuan organisasi yang efektif dan efisien.

Dharma (2003: 335) mengatakan terdapat tiga standar dalam pengukuran kinerja yang terdiri dari:

1. Kuantitas kerja.

Pengukuran hasil kerja pegawai dalam menggunakan waktu dan kecepatan tertentu dalam menyelesaikan pekerjaanya.

2. Kualitas kerja.

Mengukur mutu seorang pegawai dalam jumlah hasil pekerjaan yang diselesaikan sesuai dari target yang telah ditentukan.

3. Ketetapan waktu. Penyelesaian seluruh pekerjaan yang dilakukan oleh karyawan dengan waktu yang sudah di tetapkan.

\section{Hubungan Budaya Organisasi Terhadap Kinerja Karyawan}

Perusahaan dalam meningkatkan kinerja karyawan perlu menciptakan budaya organisasi yang baik agar perusahaan dapat mencapai tujuan yang diinginkan. Adanya hubungan antara budaya organisasi dan kinerja karyawan terdapat pada penelitian Mohamed \& Abubakar (2013) yaitu menemukan korelasi moderat yang positif antara budaya organisasi dan kinerja karyawan dan juga hasil penelitian Sulistiawan, Riadi, \& Maria (2017) yang menyatakan bahwa budaya organisasi terbukti berpengaruh signifikan terhadap variabel kinerja karyawan pada taraf signifikansi $5 \%$, dengan besar pengaruh $55,03 \%$.

Budaya organisasi yang kuat akan mendukung perkembangan kinerja karyawan serta memotivasi karyawan untuk mencapai tujuan bersama. Pada akhirnya akan membentuk perilaku karyawan ke arah tertentu sesuai yang diinginkan oleh organisasi. Selanjutnya, jenis budaya organisasi yang dibuat dalam suatu 
organisasi akan menentukan dampak terhadap kinerja karyawan. Oleh karena itu,

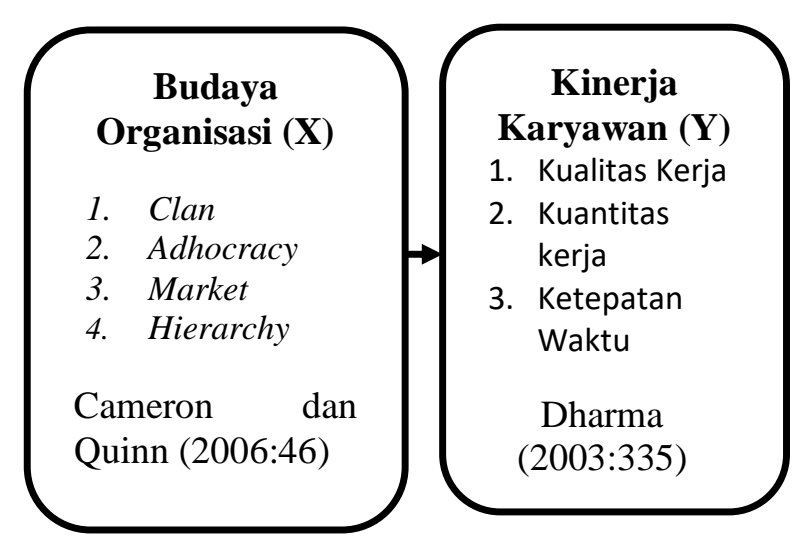

\section{Gambar 3. Paradigma Penelitian}

perusahaan sebaiknya menciptakan budaya organisasi yang sesuai dengan lingkungan perusahaan agar kinerja karyawan meningkat sehingga menguntungkan perusahaan.

Gambar 3 menunjukkan bahwa ada hubungan antar variabel budaya organisasi terhadap kinerja karyawan. Pengukuran budaya organisasi menggunakan teori

Cameron dan Quinn (2006) yang terbagi menjadi empat kuadran yaitu clan, adhocracy, market, dan hierarchy. Sedangkan dimensi kinerja yang dipakai dalam penelitian adalah dimensi menurut Dharma (2003) yaitu kualitas kerja, kuantitas kerja, dan ketepatan waktu.

Berdasarkan pembahasan dalam latar belakang, landasan teori, dan kerangka berpikir, hipotesis penelitian ini adalah sebagai berikut:

Ho : Tidak adanya pengaruh positif yang signifikan antara budaya organisasi terhadap kinerja karyawan.

Ha : Adanya pengaruh positif yang signifikan budaya organisasi terhadap kinerja karyawan.

\section{METODE}

Pada penelitian ini, metode penelitian yang digunakan untuk menjawab rumusan masalah mengenai pengaruh budaya organisasi terhadap kinerja karyawan divisi account excecutive di PT Agrodana Futures adalah dengan metode pre-experimental designs yaitu one-shot case study. Sependapat dengan Sugiyono (2013) yang menyatakan bahwa one-shot case study adalah desain penelitian yang terdiri dari satu kelompok yang diberi treatment/perlakuan yang kemudian dilakukan observasi dari hasil tersebut. Selain itu, penelitian ini juga menggunakan metode pendekatan kuantitatif, karena penelitian ini dalam mengolah data dan hasil dari data yang diperoleh disajikan dengan menggunakan angka-angka.

\section{Populasi dan Sampel}

Populasi dalam penelitian ini adalah karyawan yang bekerja di divisi account executive PT Agrodana Futures yaitu sebanyak 150 orang yang terbagi menjadi dua tim akan tetapi tetap pada di departemen marketing yang sama. Divisi bagian account executive dipimpin oleh dua manajer yang berbeda dengan pengawasan yang sama. Sampel dalam penelitian ini adalah seluruh populasi karyawan divisi account executive di PT Agrodana Futures. Berdasarkan jumlah karyawan yang ada di divisi account executive PT Agrodana Futures yaitu sebanyak 150 karyawan, Teknik sampling yang digunakan adalah nonprobability sampling yaitu sampling jenuh untuk meminimalisir outlayers yang kemungkinan akan terjadi.

\section{HASIL DAN PEMBAHASAN Identitas Responden}

Hasil penyebaran kuesioner kepada 150 responden divisi account executive di PT Agrodana Futures didapat data berdasarkan jenis kelamin, usia, lama bekerja dan pendidikan terakhir. Responden yang mengisi kuesioner ini sebagian besar berjenis kelamin wanita dengan jumlah 80 responden dengan presentase sebesar $53 \%$, sedangkan untuk responden yang berjenis kelamin lakilaki sebanyak 70 responden dengan presentase $47 \%$. Hasil penelitian ini meninjukkan bahwa berdasarkan jenis 
kelaminnya, karyawan wanita lebih banyak dibandingkan dengan karyawan pria. Sedangkan berdasarkan usia responden sebagian besar berusia kurang dari 30 tahun sebanyak 41 responden dengan presentase $73 \%$, kemudian yang berusia sekitar 30-50 tahun sebanyak 109 responden dengan presentase $27 \%$. Hasil penelitian diatas menunjukkan bahwa usia karyawan yang berusia <30 tahun adalah karyawan terbanyak di divisi account executive. Kemudian data responden berikutnya adalah mengenai lama bekerja, sebanyak 150 responden lama bekerja kurang dari 5 tahun dengan presentase $70 \%$ dan sisanya yaitu 45 responden lama bekerja dari 5-10 tahun dengan presentase sebesar 30\%. Hasil penelitian ini menunjukkan bahwa hanya sedikit karyawan saja yang bertahan 5-10 tahun di perusahaan.

\section{Analisis Deskriprif Variabel}

Pada analisis deskriptif ini akan membahas persepsi jawaban pada 102 responden setelah penghapusan outlier dikarenakan adanya data yang tidak normal sebelumnya pada 150 responden.

\section{Budaya Organisasi}

Pada variabel budaya organisasi, terdapat empat dimensi yaitu clan culture, adhocracy culture, market culture, dan hierarchy culture. Tabel 2 berikut adalah hasil penelitian analisis deskriptif pada variabel budaya organisasi:

Tabel 2. Statistik Deskriptif Budaya Organisasi Budaya Organisasi

\begin{tabular}{|l|l|l|l|l|l|}
\hline & N & Min & Max & Mean & $\begin{array}{l}\text { Std. } \\
\text { Dev }\end{array}$ \\
\hline Clan Culture & 102 & 3,00 & 5,00 & 4,4853 &, 5461 \\
\hline Adhocracy Culture & 102 & 3,00 & 5,00 & 4,4150 &, 5743 \\
\hline Market Culture & 102 & 3,00 & 5,00 & 4,4395 &, 6031 \\
\hline Hierarchy Culture & 102 & 3,00 & 5,00 & 4,4362 &, 5883 \\
\hline Budaya Organisasi & $\mathbf{1 0 2}$ & $\mathbf{3 , 0 0}$ & $\mathbf{5 , 0 0}$ & $\mathbf{4 , 4 4 4}$ & $\mathbf{5 8 8 3}$ \\
\hline Valid N (listwise) & 102 & & & & \\
\hline
\end{tabular}

Sumber: Output SPSS (2018)

$$
\text { Berdasarkan tabel diatas }
$$

menunjukkan bahwa dimensi variabel budaya organisasi memiliki nilai 4,444 yaitu berada di dalam skala interval 4,21-5,00 yang tergolong sangat tinggi atau sangat baik atau memiliki arti bahwa budaya organisasi di divisi account executive PT Agrodana Futures memiliki budaya organisasi yang sangat baik. pada kolom standar deviasi untuk variabel budaya organisasi adalah 0,58837 dan memiliki nilai mean 4,444 yang berarti standar deviasi pada variabel budaya organisasi adalah 13,23\% (standar deviasi/ mean x 100). Hasil tersebut menunjukkan bahwa standar deviasi variabel budaya organisasi kurang dari $20 \%$ yang memiliki arti bahwa variasi jawaban responden dalam memberikan jawaban adalah rendah.

Hasil analisis deskriptif budaya organisasi yang pertama adalah dimensi clan culture yang memiliki nilai rata-rata item pernyataan (mean) pada dimensi clan culture adalah sebesar 4,48 yang berada di dalam skala interval 4,21-5,00 yang tergolong sangat tinggi atau sangat baik. Hasil tersebut menunjukkan bahwa budaya organisasi yang bersifat kekeluargaan di PT Agrodana Futures sudah dijalankan dengan baik dikarenakan hasilnya lebih dominan dibandingkan dengan dimensi atau tipe budaya yang lain. Hal itu diperkuat dengan indikator-indikator pada dimensi clan yang berada di dalam skala interval 4,21-5,00 yang tergolong sangat tinggi atau sangat baik. Hal ini dibuktikan dengan perusahaan yang selalu melakukan kegiatan sharing pada waktu tertentu sehingga karyawan bisa dengan leluasa dan saling terbuka dalam menyampaikan aspirasi atau kendala-kendala yang terjadi. Hal lain juga didukung oleh suasana kantor yang nyaman dan orangorang yang bersahabat sehingga suasana di kantor tidak terasa kaku. Fasilitas perusahaan juga mendukung bagaimana karyawan bekerja, PT Agrodana Futures sendiri memberikan fasilitas berupa psikolog untuk menangani masalah-masalah yang dialami oleh karyawan dalam bekerja. Contoh lain perusahaan sejenis yang menerapkan clan culture adalah PT Bank Muamalat Indonesia 
Bogor Area. Berdasarkan hasil penelitian Sumardjono (2016), PT Bank Muamalat Indonesia Bogor Area telah menerapkan budaya klan. Hasil rata-rata budaya mengacu pada budaya klan yang merupakan yang paling dominan, yang berfokus untuk menempatkan prioritas keterlibatan semua karyawan dalam kerja tim untuk mencapai tujuan organisasi karena memberikan keuntungan kepada organisasi dan kepada semua pemangku kepentingan dan pemegang saham organisasi.

Kedua adalah dimensi adhocracy culture yang terdiri dari enam indikator, yaitu organisasi menuntut anggota berani mengambil resiko, kewirausahaan, inovasi, dan pengambilan resiko, orientasi terhadap pengambilan resiko, inovasi, kebebasan, dan keunikan, komitmen, pengembangan kemampuan, dan fokus pada hal-hal penting, penekanan terhadap penemuan sumber daya baru dan penciptaan tantangan baru, dan sukses berdasarkan terbentuknya produk baru. Berdasarkan Tabel 4.7 nilai mean dimensi adhocracy culture yaitu 4,4150 yang berada dalam kategori sangat baik. Hal itu diperkuat dengan indikatorindikator rata-rata pada dimensi adhocracy yang berada di dalam skala interval 4,215,00 yang tergolong sangat tinggi atau sangat baik. Cara kreatif yang biasa dilakukan PT Agrodana Futures dalam mencari nasabah adalah selalu melakukan kegiatan sosial contohnya seminar, beauty class, pelayanan kesehatan, donor darah, tajil akbar, dan lain-lain. Kegiatan sosial yang dilakukan perusahaan terhadap masyarakat luar juga diiringi dengan memberikan informasi dalam investasi di bursa berjangka. Selain adanya inovasi dengan kreativitas di perusahaan, terdapat juga pengambilan resiko yang dilakukan oleh karyawan. Pengambilan resiko yang dilakukan adalah kepada nasabah berupa pengenalan mengenai investasi di bursa berjangka. Terkadang karyawan menawarkan dan memberikan suatu produk atau barang tertentu kepada calon nasabah agar bergabung dalam investasi ini. Jika pada suatu saat nasabah sudah bergabung dan mengalami kerugian, maka karyawan tersebut juga akan mengalami kerugian, dikarenakan barang yang diberikan kepada nasabah merupakan komisi pribadi yang dimiliki oleh karyawan tersebut.

Ketiga adalah dimensi market culture dengan nilai mean adalah sebesar 4,4395 yang berada dalam kategori sangat tinggi atau sangat baik. Market culture terdiri dari enam indikator yaitu organisasi sangat berorientasi terhadap hasil, pemimpin fokus pada pencapaian hasil, manajemen berorientasi terhadap persaingan, organisasi kokoh karena adanya prestasi dan pencapaian tujuan, organisasi menekankan pada kompetisi dan prestasi, dan sukses didefinisikan dengan memenangkan kompetisi. Indikator rata-rata pada dimensi market memiliki nilai yang berada di dalam skala interval 4,21-5,00 yang tergolong sangat tinggi atau sangat baik.

PT Agrodana Futures sangat berorientasi terhadap hasil, karena PT Agrodana Futures sendiri merupakan perusahaan yang bergerak di bidang investasi bursa berjangka. Artinya, perusahaan ini bergantung pada hasil yang diterima dari setiap nasabah atau jumlah transaksi yang didapat. Setiap bulannya PT Agrodana Futures memiliki target-target yang harus dicapai oleh para manajer, asisten manajer, dan anggota dari setiap timnya. Semakin banyak nasabah atau jumlah transaksi yang di dapat maka semakin besar hasil yang didapat. PT Agrodana Futures tentunya bersaing dengan perusahaan lain yang bergerak dibidang yang sama. Oleh karena itu, tingginya persaingan dipasar dalam mendapatkan nasabah cukup sulit. Sehingga diperlukan strategi-strategi untuk mengajak nasabah bergabung.

Dimensi keempat adalah hierarchy culture yang terdiri dari indikator-indikator berupa organisasi terkontrol dan terstruktur, pemimpin bersifat sebagai koordinator, rasa aman pada karyawan, peraturan dan 
kebijakan formal, menekankan kepermanenan dan stabilitas, dan sukses atas dasar efisiensi. Pengendalian dan kontrol karyawan di PT Agrodana Futures berupa absensi setiap harinya mulai dari jam masuk kantor dan jam pulang kantor, terlambat setiap satu menitnya akan terkena potongan gaji. Jika tidak hadir selama tiga hari berturut-turut tanpa adanya laporan maka dilakukan peneguran, dan jika izin maupun sakit harus memberikan surat. Absensi kehadiran setiap karyawan minimal $70 \%$ dan pada saat pelaksanaan kerja setiap karyawan wajib membuat laporan kegiatan setiap harinya. Sehingga dapat disimpulkan bahwa

peraturan-peraturan yang dibuat oleh perusahaan sudah diterapkan dengan baik.

\section{Kinerja Karyawan}

Pada variabel kinerja karyawan digunakan dimensi kualitas kerja, kuantitas kerja, dan ketepatan waktu. Hasil variabel kinerja karyawan divisi account executive di PT Agrodana Futures termasuk ke dalam kategori "sangat tinggi" dengan nilai mean sebesar 4,3670 yang di dalam skala interval 4,21-5,00 yang tergolong sangat tinggi atau sangat baik. Sehingga dapat diartikan bahwa kinerja karyawan divisi account executive di PT Agrodana Futures sangat baik.

Tabel 3. Statistik Deskriptif Kinerja Karyawan Kinerja Karyawan

\begin{tabular}{|l|l|l|l|l|l|}
\hline & N & Min & Max & Mean & $\begin{array}{l}\text { Std. } \\
\text { Dev }\end{array}$ \\
\hline Kualitas Kerja & 102 & 3,00 & 5,00 & 4,2679 &, 6325 \\
\hline Kuantitas kerja & 102 & 3,00 & 5,00 & 4,4640 &, 5423 \\
\hline Ketepatan Waktu & 102 & 3,00 & 5,00 & 4,3692 &, 5838 \\
\hline Kinerja Karyawan & $\mathbf{1 0 2}$ & $\mathbf{3 , 0 0}$ & $\mathbf{5 , 0 0}$ & $\mathbf{4 , 3 6 7 0}$ & $\mathbf{5 8 6 2}$ \\
\hline Valid N (listwise) & 102 & & & & \\
\hline
\end{tabular}

Sumber: Output SPSS (2018)

Pertama adalah dimensi kualitas kerja yang memiliki tiga indikator yaitu penilaian kualitas kerja, kualitas hasil kerja sesuai dengan ketentuan, dan bekerja dengan standar mutu perusahaan. Berdasarkan Tabel 3 dimensi kualitas memiliki nilai mean 4,2679. Hal ini didukung oleh nilai mean setiap indikator yang berada di dalam skala interval 4,21-5,00 yang tergolong sangat tinggi atau sangat baik. Akan tetapi, dimensi ini memiliki nilai mean terendah dibandingkan dengan dimensi lain. Terdapat satu indikator dalam dimensi kualitas kerja yaitu kualitas hasil kerja sesuai dengan ketentuan yang memiliki nilai mean sebesar 4,2549. Kualitas kerja perusahaan ditentukan oleh hasil kerja karyawan yang sesuai dengan aturan perusahaan yang terdiri dari jumlah kehadiran, laporan kegiatan yang dilakukan, margin yang diperoleh dari nasabah, dan sikap karyawan. Kualitas kerja yang baik dipengaruhi oleh hasil kualitas kerja karyawan itu sendiri. Hal lain yang dapat mempengaruhi kualitas kerja adalah disebabkan oleh kegiatan appointment. Kegiatan appointment adalah pertemuan dengan calon nasabah untuk menawarkan peluang bisnis. Jika calon nasabah ternyata sudah pernah berkecimpung di dalam bisnis futures sebelumnya, maka fokus pertemuan yakni meyakinkan calon konsumen untuk bersedia melakukan investasi. Sementara jika calon konsumen sama sekali awam dengan bisnis futures, karyawan (financial consultant) pertama-tama akan memberikan sedikit edukasi mengenai perdagangan berjangka dan mekanisme berbisnis pada bidang futures. Kendala yang sering ditemukan dalam kegiatan ini adalah pada saat dilakukan pertemuan dengan calon nasabah, tidak semua calon nasabah ingin berinvestasi. Hal ini dikarenakan kurangnya kepercayaan calon nasabah untuk berinvestasi dalam bisnis ini dan bisnis ini sering dikaitkan oleh perjudian. Oleh karena itu, setiap karyawan perlu memiliki motivasi yang tinggi dan menyadari pentingnya kualitas hasil kerja perusahaan agar dapat menguntungkan perusahaan dan menguntungkan karyawan itu sendiri. Kesejahteraan karyawan pun perlu diperhatikan seperti kebutuhan fisiologis, kebutuhan keamanan, kebutuhan kebersamaan, kebutuhan penghargaan, dan kebutuhan aktualisasi diri atau yang dapat 
kita sebut adalah teori hierarki kebutuhan Maslow.

Dimensi kedua yaitu kuantitas kerja, berdasarkan hasil Tabel 3 kuantitas kerja memiliki nilai mean tertinggi yaitu 4,4640 dibandingkan dengan dimensi kualitas kerja dan ketepatan waktu. Hal itu diperkuat dengan indikator-indikator dimensi kuantitas kerja berada di dalam skala interval 4,21-5,00 yang tergolong sangat tinggi atau sangat baik. Kuantitas kerja terdiri dari indikator berupa target kerja yang ditetapkan perusahaan, volume hasil pekerjaan, dan target kerja dapat dipenuhi dengan baik. Hasil tersebut menunjukkan bahwa kinerja karyawan dalam mencapai kuantitas kerja di PT Agrodana Futures sudah dijalankan dengan baik dikarenakan hasilnya lebih dominan dibandingkan dengan dimensi kinerja karyawan yang lainnya. Setiap bulannya divisi account executive memiliki target untuk mendapatkan nasabah atau transaksi sekiranya sekitar $90 \%$ setiap bulannya. Hasil pendapatan dari setiap bagian yaitu manajer, asisten manajer, dan bawahannya kemudian akan diakumulasikan berdasarkan dari nasabah yang berinvestasi atau transaksi yang didapat. Hal ini membuktikan bahwa kuantitas kerja di perusahaan sudah jelas walaupun perusahaan hanya mampu mencapai target sekitar $35 \%$ hingga $75 \%$ saja pada tahun 2017.

Ketiga adalah dimensi ketepatan waktu yang memiliki tiga indikator, yaitu pekerjaan dilaksanakan dengan tepat waktu, penyelesaian pekerjaan sesuai dengan standar perusahaan, dan efisiensi dalam bekerja. Berdasarkan Tabel 3 dimensi ketepatan waktu memiliki nilai mean 4,3692. Hal ini didukung oleh nilai mean setiap indikator yang berada di dalam skala interval 4,21-5,00 yang tergolong sangat tinggi atau sangat baik. Penyelesaian pekerjaan yang dilakukan karyawan sudah dilaksanakan sesuai standar perusahaan yang berupa kegiatan marketing prospecting. Marketing prospecting ini terdiri dari empat kegiatan yaitu canvassing, contacting, appointment, dan closing. Selain itu, mayoritas karyawan sudah dapat melaksanakan pekerjaannya dengan tepat waktu dikarenakan masing-masing dari karyawan juga mengejar penghasilan untuk diri mereka sendiri.

\section{Analisis Regresi Sederhana}

Analisis regresi sederhana dalam penelitian ini digunakan untuk mengetahui arah positif atau negatif hubungan antara variabel budaya organisasi dengan variabel kinerja karyawan.

Berdasarkan tabel 4 dapat dilihat bahwa nilai konstanta (a) sebesar 14,177 sedangkan nilai koefisien regresi (b) sebesar 0,236 . Oleh karena itu, persamaan regresi yang dapat diperoleh dalam penelitian ini adalah $\mathrm{Y}=14,177+0.236 \mathrm{X}$.

Tabel 4. Analisis Regresi

\begin{tabular}{|l|l|l|l|l|l|}
\hline Model & \multicolumn{2}{|c|}{$\begin{array}{l}\text { Unstandardied } \\
\text { Coefficients }\end{array}$} & $\begin{array}{l}\text { Standardizd } \\
\text { Coefficients }\end{array}$ & T & Sig. \\
\cline { 2 - 5 } & B & $\begin{array}{l}\text { Std. } \\
\text { Error }\end{array}$ & Beta & & \\
\hline $\begin{array}{l}\text { (Constant) } \\
\text { Budaya } \\
\text { Organisasi }\end{array}$ & 14,177 & 4,212 & & 3,366 &, 001 \\
\hline
\end{tabular}

Sumber: Output SPSS (2018)

Nilai a dan b pada persamaan regresi diatas dapat diartikan sebagai berikut:

a. Konstanta sebesar 14,177 dapat diartikan jika budaya organisasi bernilai $\quad(X=0)$ maka kinerja karyawan yang tercapai hanya sebesar 14,177.

b. Budaya organisasi memiliki nilai koefisien regresi sebesar 0,236 yang memiliki arti bahwa setiap penambahan satu angka budaya organisasi dengan koefisien bernilai positif, maka kinerja karyawan akan mengalami peningkatan sebesar 0,236 . Sehingga, semakin naik atau meningkatnya budaya organisasi maka nilai kinerja karyawan pun akan meningkat. 


\section{Analisis Korelasi}

Analisis korelasi digunakan untuk mengetahui adanya hubungan antara dua dua variabel yaitu budaya organisasi dan kinerja karyawan di divisi account executive PT Agrodana Futures serta untuk mengetahui hubungan arah yang terjadi.

Berdasarkan hasil Tabel 5 dapat dilihat bahwa nilai korelasi antara variabel budaya organisasi dan kinerja karyawan adalah 0,473 yang terletak pada interval $+0,30$ sampai dengan $+0,49$.

Sehingga dapat dikatakan bahwa hubungan antara variabel budaya organisasi dan kinerja karyawan memiliki hubungan positif yang sedang. Nilai korelasi pearson menunjukkan nilai yang positif yaitu hubungan antara variabel antara budaya organisasi dan kinerja karyawan adalah searah. Semakin tinggi budaya organisasi maka semakin meningkat kinerja karyawan.

Tabel 5. Analisis Korelasi

\begin{tabular}{|l|l|l|l|}
\hline \multicolumn{2}{|c|}{} & \multicolumn{1}{|c|}{$\begin{array}{c}\text { Budaya } \\
\text { Organisasi }\end{array}$} & $\begin{array}{c}\text { Kinerja } \\
\text { Karyawan }\end{array}$ \\
\hline \multirow{3}{*}{$\begin{array}{l}\text { Budaya } \\
\text { Organisasi }\end{array}$} & $\begin{array}{l}\text { Pearson } \\
\text { Correlation }\end{array}$ & 1 &, 473 \\
\cline { 2 - 4 } & Sig. (2-tailed) & &, 000 \\
\cline { 2 - 4 } & $\mathrm{N}$ & 102 & 102 \\
\hline \multirow{3}{*}{$\begin{array}{l}\text { Kinerja } \\
\text { Karyawan }\end{array}$} & $\begin{array}{l}\text { Pearson } \\
\text { Correlation }\end{array}$ &, 473 & 1 \\
\cline { 2 - 4 } & Sig. (2-tailed) &, 000 & 102 \\
\cline { 2 - 4 } & $\mathrm{N}$ & 102 & 1 \\
\hline
\end{tabular}

Sumber: Output SPSS (2018)

\section{Koefisien Determinasi}

Pengujian koefisien determinasi dalam penelitian ini adalah untuk mengetahui seberapa besar kontribusi variabel independen yaitu budaya organisasi terhadap variabel dependen yaitu kinerja karyawan.

Tabel 6. Koefisien Determinasi

\begin{tabular}{|l|l|l|l|l|}
\hline Model & $\mathrm{R}$ & $\begin{array}{c}\mathrm{R} \\
\text { Square }\end{array}$ & $\begin{array}{c}\text { Adjusted } \\
\mathrm{R} \text { Square }\end{array}$ & $\begin{array}{c}\text { Std. } \\
\text { Error of } \\
\text { the } \\
\text { Estimate }\end{array}$ \\
\hline 1 &, $513^{\mathrm{a}}$ &, 263 &, 255 & 2,76085 \\
\hline
\end{tabular}

Sumber: Output SPSS (2018)
Berdasarkan Tabel 6, dapat dilihat bahwa hasil koefisien determinasi ( $R$ square) adalah 0,263. Hal ini menunjukkan bahwa hasil koefisien determinasi antara budaya organisasi dan kinerja karyawan adalah sebesar 0,263 atau sebesar 26,3\%. Sementara sisanya yaitu sebesar $73,7 \%$ berkontribusi terhadap faktor-faktor lain yang tidak dijelaskan di dalam penelitian ini.

\section{Pengaruh Budaya Organisasi Terhadap Kinerja Karyawan}

Berdasarkan hasil penelitian dengan penyebaran kuesioner terhadap 102 responden karyawan divisi account executive di PT Agrodana Futures, terdapat hubungan antara budaya organisasi dan kinerja karyawan yang dapat dilihat pada analisis korelasi sebesar 0,473 dan terletak pada interval +0,30 sampai dengan $+0,49$. Sehingga dapat dikatakan bahwa terdapat hubungan positif yang signifikan.

Selanjutnya adalah hasil uji analisis regresi budaya organisasi yang mempunyai pengaruh positif terhadap kinerja karyawan yang dilakukan. Terdapat hasil dari konstanta (a) sebesar 14,177 dan (b) sebesar 0,236, sehingga menghasilkan persamaan $\mathrm{Y}=$ 14,177 + 0,236X. Hal tersebut mengartikan bahwa setiap ada penambahan satu angka budaya organisasi dengan koefisien regresi bernilai positif, maka kinerja karyawan akan meningkat sebesar 0,236. Sedangkan jika budaya organisasi sama dengan nol, maka nilai kinerja karyawan adalah sebesar 14,177. Selain itu, hasil koefisien determinasi menunjukkan bahwa budaya organisasi memberikan kontribusi terhadap kinerja karyawan sebesar $26,3 \%$. Sementara sisanya yaitu sebesar $73,7 \%$ berkontribusi terhadap faktor-faktor lain yang tidak dijelaskan di dalam penelitian ini.

Hasil ini memiliki kesamaan dengan hasil penelitian dari Sulastri, Ghalib, \& Taharuddin (2017) yang menunjukkan budaya organisasi terbukti memiliki kontribusi positif dan signifikan terhadap variabel kinerja karyawan dengan besar 
kontribusi 55,03\%. Hal tersebut menunjukkan pengaruh hasil presentase yang lebih besar dibandingkan penelitian ini. Selain itu, terdapat perbedaan variabel independen yang dipakai selain budaya organisasi yaitu variabel motivasi dan variabel kepuasan kerja. Dimensi antara budaya organisasi dan kinerja karyawan yang digunakan juga berbeda dengan penelitian ini. Sedangkan tujuh penelitian terdahulu lainnya memiliki hasil budaya organisasi dan kinerja karyawan berpengaruh terhadap variabel lain seperti lingkungan kerja, motivasi kerja, dan kepuasan kerja.

Hasil uji statistik F pada penelitian ini menunjukkan bahwa $\mathrm{F}$ hitung $>\mathrm{F}$ tabel yaitu $35,636>3,94$ dengan taraf signifikan 5\% dapat disimpulkan bahwa model regresi dalam penelitian ini adalah diterima yang berarti Ho ditolak dan $\mathrm{Ha}$ diterima. Nilai signifikansi pada uji statistik $\mathrm{F}$ adalah sebesar 0,000 hal ini menunjukkan bahwa nilai tersebut lebih kecil dari nilai probabilitasnya yaitu sebesar 0,05. Sehingga menunjukkan bahwa adanya pengaruh yang budaya organisasi yang signifikan terhadap kinerja karyawan di divisi account execuitive PT Agrodana Futures. Berdasarkan uji $t$ menunjukkan nilai signifikansi adalah sebesar 0,000 hal ini menunjukkan bahwa nilai tersebut lebih kecil dari nilai probabilitasnya yaitu sebesar 0,05 dan nilai $t$ hitung adalah 5,970 dengan menggunakan tingkat signifikansi 5\%. Kemudian diperoleh diperoleh nilai $\mathrm{T}$ tabel adalah sebesar 1,66023 sehingga dapat disimpulkan bahwa $\mathrm{T}$ hitung $>\mathrm{T}$ tabel yaitu 5,970>1,66023 . Oleh karena itu, kesimpulannya adalah Ho ditolak dan Ha diterima yang berarti adanya pengaruh yang signifikan antara budaya organisasi terhadap kinerja karyawan.

\section{KESIMPULAN DAN SARAN Kesimpulan}

1. Budaya organisasi divisi account executive di PT Agrodana Futures berada dalam kategori sangat tinggi atau sangat baik dengan nilai mean sebesar 4,444 yang diukur berdasarkan empat dimensi dari Cameron dan Quinn (2006), yaitu clan culture, adhocracy culture, market culture, dan hierarchy culture. Hasil dari keempat dimensi tersebut menunjukkan bahwa PT Agrodana Futures lebih dominan memiliki budaya clan dibandingkan budaya lain walaupun adhocracy culture, market culture, dan hierarchy culture sama-sama memiliki nilai mean yang sangat tinggi. Akan tetapi, ada satu indikator dalam dimensi clan culture yang memiliki nilai mean terendah dibandingkan dengan yang lain sehingga, hal ini perlu ditingkatkan lagi oleh perusahaan.

2. Kinerja karyawan divisi account executive di PT Agrodana Futures berada dalam kategori sangat tinggi atau sangat baik dengan nilai mean sebesar 4,3670 yang diukur berdasarkan tiga dimensi menurut Dharma (2003), yaitu kualitas kerja, kuantitas kerja, dan ketepatan waktu. Hasil dari ketiga dimensi tersebut menunjukkan bahwa dimensi kuantitas kerja memiliki nilai mean tertinggi dan nilai mean terendah adalah dimensi kualitas kerja.

3. Hasil penelitian ini menunjukkan adanya pengaruh positif yang signifikan antara variabel budaya organisasi dengan variabel kinerja karyawan. Besarnya kontribusi budaya organisasi terhadap kinerja karyawan divisi account executive di PT Agrodana Fututres adalah sebesar 26,3\%. Sementara sisanya yaitu sebesar $73,7 \%$ berkontribusi terhadap faktor-faktor lain yang tidak dijelaskan di dalam penelitian ini.

\section{Saran}

Berdasarkan kesimpulan yang sudah dipaparkan, berikut adalah beberapa saran yang dapat memberikan masukkan positif mengenai pengaruh budaya organisasi terhadap kinerja karyawan: 
1. Budaya organisasi divisi account executive di PT Agrodana Futures Bandung sudah tergolong sangat tinggi atau sangat baik, terutama perusahaan perlu mempertahankan atau meningkatkan budaya yang sudah ada yaitu budaya clan. Hanya saja aspek dalam budaya clan yang perlu ditingkatkan adalah indikator pengembangan sumber daya manusia (SDM) perusahaan. Pada saat perekrutan karyawan baru, perusahaan perlu melakukan tes psikologi kepada calon pelamar. Fungsi dari tes psikologi tersebut agar perusahaan dapat mengetahui psikologi dan potensi karyawan yang cocok bagi perusahaan. Selain itu, perusahaan perlu memberikan kegiatan staff development, baik on the job training maupun off the job training kepada orang yang tertarik untuk mengembangkan profesi dibidang marketing dan melakukan promosipromosi melalui iklan di media cetak maupun media internet atau sosial media. Hal lain yang bisa dilakukan adalah melakukan seminar-seminar terbuka untuk memberikan product knowledge kepada mahasiswa di universitas-universitas yang diharapkan nantinya lulusan mahasiswa fresh graduate akan tertarik dalam bisnis ini. Sedangkan untuk menarik perhatian investor, perlu dilakukan pengklasifikasian produk-produk tertentu agar kalangan mahasiswa dan orang yang sudah bekerja bisa melakukan investasi sesuai dengan kemampuan mereka. Seharusnya PT Agrodana Futures Bandung menerapkan budaya market karena perusahaan sangat berorientasi terhadap hasil dan berfokus dalam mendapatkan customer.

2. Kinerja karyawan divisi account executive di PT Agrodana Futures sudah tergolong sangat tinggi atau sangat baik, terutama pada dimensi kuantitas kerja. Akan tetapi, dimensi kinerja karyawan yang memiliki nilai mean terendah adalah dimensi kualitas kerja dengan indikator kualitas hasil kerja sesuai dengan ketentuan. Sehingga, hal ini perlu ditingkatkan lagi oleh perusahaan dengan cara memotivasi karyawan agar semangat dalam menjalani pekerjaan, atau memiliki dan mempersatukan pandangan yang sama untuk memajukan perusahaan. Selain itu, pemberian reward pada karyawan yang berprestasi dan pemberian punishment kepada karyawan yang tidak taat terhadap aturan juga diperlukan.

3. Diharapkan untuk para peneliti selanjutnya dalam melakukan penelitian di PT Agrodana Futures dapat menggunakan variabel bebas lain seperti motivasi kerja, stres kerja, kepuasan kerja, lingkungan kerja atau kompensasi kerja.

\section{DAFTAR PUSTAKA}

Atmosoeprapto, K. (2001). Produktivitas Aktualisasi Budaya Perusahaan. Jakarta: PT Elex Media Komputindo Kelompok Gramedia.

Cameron, K. S., \& Quinn, R. E. (2006). Diagnosing and Changing Organizational Culture: Based in the Competing Values Framework $(C V F)$, revised ed., MA. AddsionWesley: Reading: MA.

Dharma, A. (2003). Manajemen Supervisi. Jakarta: PT. Raja Grafindo Persada.

Kreitner, R., \& Kinicki, A. (2014). Perilaku Organisasi Edisi 9 Buku 1. Jakarta: Salemba Empat.

Luthan, F. (2005). Organizational Behavior Seventh Edition. New York: McGraw-Hill Inc.

Mangkunegara, A. A. (2010). Manajemen Sumber Daya Manusia. Bandung: Remaja Rosdakarya. 
Mangkunegara, A. A. (2011). Manajemen Sumber Daya Manusia Perusahaan. Bandung: PT Remaja Rosdakarya.

Mohamed, A. I., \& Abubakar, A. A. (2013). The Impact of Organizational Culture on Employees Performance of Mogadishu Universities. Academic Research International Vol. 4 No. 6 ISSN: 2223-9944.

Rivai, V. (2008). Manajemen Sumber Daya Manusia Untuk Perusahaan dari Teori ke Praktik. Jakarta: PT Raja Grafindo Persada.

PT Agrodana Futures. (2018). Jumlah Keterlambatan Karyawan Tahun 2017.

PT Agrodana Futures. (2018). Kinerja Karyawan Divisi Account Executive Tahun 2017.

Robbins, S. P. (2003). Organizational Behavior 10th Edition. New Jersey: Pearson Education, Inc.

Robbins, S. P. (2013). Organizational Behaviour 15th Edition. New Jersey: Prentice Hall.

Santoso, S. (2012). Analisis SPSS pada Statistik Parametrik. Jakarta: PT Elex Media Komputindo.

Sugiyono. (2013). Metode Penelitian Kuantitatif, Kualitatif dan $R \& D$. Bandung: Alfabeta.

Sulastri, E., Ghalib, S., \& Taharuddin. (2017). Pengaruh Budaya Organisasi, Motivasi, Dan Kepuasan Kerja Terhadap Kinerja Karyawan PT.PLN (Persero) Wilayah Kalimantan Selatan dan Kalimantan Tengah Area Kuala Kapuas. Jurnal Bisnis dan Pembangunan Vol 6, No. 1, ISSN 2541-178X.

Sulistiawan, D., Riadi, S. S., \& Maria, S. (2017). Pengaruh budaya organisasi dan lingkungan kerja terhadap kinerja pegawai. Journal FEB Unmul Volume 14 (2) ISSN: 1907 3011, 6169.
Sulistiyani, A. T., \& Rosidah. (2003). Manajemen Sumber Daya Manusia. Yogyakarta: Graha Ilmu.

Triatna, C. (2015). Perilaku Organisasi. Bandung: PT Remaja Rosdakarya. 